\title{
Addiction profile in probation practices in Turkey: 5 -year data analysis
}

This article was published in the following Dove Press journal:

Neuropsychiatric Disease and Treatment

27 August 2015

Number of times this article has been viewed

\author{
Ahmet Bülent Yazici' \\ Esra Yazici \\ Neslihan Akkisi Kumsar' \\ Atila Erol ${ }^{2}$ \\ 'Department of Psychiatry, Sakarya \\ University Training and Research \\ Hospital, ${ }^{2}$ Department of Psychiatry, \\ Sakarya University Faculty of \\ Medicine, Sakarya, Turkey
}

Introduction: While drug addiction is a global problem, it is important for every region to know the general features of its own addicts in order to develop effective treatment programs This study presents sociodemographic data of the individuals diagnosed with drug addiction. Methods: In this study, data of the patients between the years of 2009 and 2014 were retrospectively analyzed. The patients were assessed at psychiatry polyclinics according to probation practices of drug abuse. The study involved 513 patients in whom drug positivity was detected in urine analysis at least once and whose diagnoses were confirmed with a clinical interview.

Results: According to this study, a majority of the addicts were detected in 2013. Males made up $98.2 \%$ of the sample population, their average age was $32.12 \pm 10.21$ years, and minimum and maximum ages for the first drug use were 7 years and 45 years, respectively. Marijuana use was found in $90.8 \%$ of the patients, $90 \%$ of them were living with their families, and $59.6 \%$ of them held a regular job. Treatment response was related with age of first use of drugs, duration of use drugs, and prior treatment anamnesis of the patients.

Conclusion: In this study, it was determined that the drug which was most frequently was used marijuana. The risk of drug addiction can affect any individual in society, regardless of their education, occupation, or social support levels. Alternative treatment models, especially for chronic and long-term users, should be researched.

Keywords: addiction, crime, cannabis, substance use

\section{Introduction}

Drug addiction is a major health problem that affects Turkey as well as the rest of the world. $^{1,2}$ In order to deal with drug abuse and the relevant legal problems associated with it, various methods, such as "probation" (P), have been newly applied throughout the world. Current $P$ practices and laws were defined and earlier applied in the USA and Europe than in Turkey. ${ }^{3,4}$ Although the rate of illegal substance use in Turkey is lower than that found in western countries, individual and social problems involving substance use have increased rapidly. ${ }^{1,2}$ The prevalence of these problems required the creation of new legal regulations regarding these issues in Turkey. " $\mathrm{P}$ " is a concept wherein society rather than a penal institution imposes sanctions or preventive measures for a criminal offense. 5 "P" refers to the suspension of punishment detection, the suspension of the execution of punishment as applied in Continental Europe, the suspension of judgment, and the lack of an imposition of a penalty despite the detection of criminality. ${ }^{5}$ Sanctions related to the treatment of drug, stimulant, or volatile substance addicts and alcohol addicts have been newly imposed for individuals in Turkey who have received a $\mathrm{P}$ due to the offense of "Buying, accepting or keeping drugs or stimulants for use" cited in article 191 of Turkish Criminal Code No. 5237 and for individuals who have received a judicial control decision pursuant to article 109 of Turkish Criminal Code No. 5271.6 In the relevant law, the law dated June 18, 2014 was amended. ${ }^{7,8}$ Until amendments are made to the related law,
Correspondence: Ahmet Bülent Yazici Department of Psychiatry, Sakarya University Training and Research Hospital, Korucuk Street, Sakarya 54290, Turkey

Tel +905325994988

Fax +90264255 2105

Email a.bulentyaz@gmail.com (c) (i) (5) 2015 Yazici et al. This work is published by Dove Medical Press Limited, and licensed under Creative Commons Attribution - Non Commercial (unported, v3.0) cc) (i) 1 (icense. The full terms of the License are available at http://creativecommons.org/licenses/by-nc/3.0/. Non-commercial uses of the work are permitted without any further permission from Dove Medical Press Limited, provided the work is properly attributed. Permissions beyond the scope of the License are administered by Dove Medical Press Limited. Information on how to request permission may be found at: http://www.dovepress.com/permissions.php 
persons who have been ordered by the $\mathrm{P}$ bureaus pursuant to the current legislation are required to apply to health institutions within 5 days. ${ }^{9}$ Once at the institution, addicts must undergo urine tests three times, with 15 days between each test, as well submit to a clinical interview, and if the results of the tests are positive and the interviews confirm the results of drug use, then such persons must enter a 6-week treatment program. In this program, individual-oriented or group-oriented semi-structured psycho-education practices are applied once a week. If it is decided that the relevant person is addicted after the personal interview and repeated toxicological analyses, he/she should be directed to an addiction treatment center..$^{5,9}$ Many provinces in Turkey lack any information about the frequency and features of drug use. Although $\mathrm{P}$ data are unable to provide precise overall information, they can help to provide service providers with a preliminary understanding of the problems.

\section{Methods}

This study provides the data obtained following the conduct of a retrospective analysis of the files for which application for $\mathrm{P}$ practice was made to the psychiatry polyclinic of Sakarya Training and Research Hospital (STRH) due to drug use.

Approval of the Sakarya University, Medical Faculty Ethics Committee was received for the study.

\section{$\mathrm{P}$ procedure}

In cases where the court realizes that an individual has a drug addiction and is heavily addicted, they are sent to our hospital to undergo a 6 -week treatment program. ${ }^{9}$ These patients are subjected to urine drug screening test and a clinical interview. If drug screening test returns a positive result and this situation is consistent with a clinical interview, the patient participates in a 6-week treatment program, which begins within 5 days following the last urine analysis. On the first day of treatment, the patient fills out a sociodemographic data form during the preinterview process, conducted before the patient meets the doctor. During the program; patients had six sessions of psychoeducation about addiction and brief supportive psychotherapy. At the end of the treatment program if they had substance negative urine test results for the last 3 weeks (second half of the program) in line with their clinical evaluation, they were accepted as responders. If they had substance positivity in urine tests, they were evaluated as nonresponders to the treatment and sent to a further treatment program in specialized addiction research and treatment centers.

\section{Sociodemographic data and drug use form}

This form is a questionnaire including the patient's age, the person/people with whom the patient lives, and drug use frequency. It is a one-page short form that the Ministry requires all patients under judicial cases to fill out.

\section{Statistical analysis}

SPSS Statistics version 13.0 (SPSS Inc., Chicago, IL, USA) was used for conducting statistical analysis in this study. Before comparing the average figures of linear variables, Student's $t$-test and Mann-Whitney $U$ test were used in homogeneous and nonhomogeneous groups, respectively. Levene's test was conducted on all groups included in the study.

\section{Results}

This study was conducted on 513 people who presented to the psychiatry polyclinic of STRH within the scope of P between October 2009 and December 2014. All of the study participants were diagnosed with a "drug addiction" following the conduct of a clinical interview and were thereby included in a 6-week treatment program.

\section{Sociodemographic data}

Of the patients participated in the treatment program, $98.2 \%$ were male. The average age of the participants was $32.12 \pm 10.21$ (range: 16-69 years) years. While $8.7 \%$ of the patients $(n=44)$ lived alone, $90 \%$ of them $(n=457)$ lived with their families. The patients who had to undergo the 6-week treatment program while still under incarceration corresponded to $0.6 \%(n=3)$ of the participating patients, and those who were not under incarceration corresponded to $1.8 \%(n=9)$. A total of $78.8 \%$ of the patients lived in the city center.

When the working conditions of the patients were evaluated, it was observed that the percentage of patients with regular work, those without regular work, and casual employees were $59.6 \%$ $(n=304), 31.6 \%(n=151)$, and $10.8 \%(n=55)$, respectively.

In looking at the years of application and rate of new applications per year, it was determined that the most applications by new patients were made in 2013 (Table 1).

After analyzing the responses to the question of the age at which the patient used drugs for the first time, the results

Table I Distribution of the patients by years within the scope of 6-week $P$ program

\begin{tabular}{|c|c|c|c|c|}
\hline \multirow{2}{*}{$\begin{array}{l}\text { Application } \\
\text { year }\end{array}$} & \multirow[t]{2}{*}{$\mathbf{n}$} & \multirow[t]{2}{*}{$\%$} & \multicolumn{2}{|l|}{ Application type } \\
\hline & & & First diagnosis, $n$ & Former patient, $n$ \\
\hline 2009 & 9 & 1.8 & 7 & 2 \\
\hline 2010 & 64 & 12.5 & 40 & 24 \\
\hline 2011 & 55 & 10.7 & 32 & 23 \\
\hline 2012 & 113 & 22.0 & 47 & 66 \\
\hline 2013 & 162 & 31.6 & 119 & 43 \\
\hline 2014 & 110 & 21.4 & 86 & 24 \\
\hline Total & 513 & 100 & 331 & 182 \\
\hline
\end{tabular}

Abbreviation: $\mathrm{P}$, probation. 
Table 2 Education features of $P$ patients (5 years)

\begin{tabular}{llll}
\hline Education status & $\mathbf{n}$ & $\%$ & Valid \% \\
\hline Never went to school & II & 2.1 & 2.2 \\
I-5 years & 178 & 34.7 & 35.7 \\
$6-8$ years & 142 & 27.7 & 28.4 \\
9-I2 years & 145 & 28.3 & 29.1 \\
Over I2 years & 23 & 4.5 & 4.6 \\
Valid in total & 499 & 97.3 & 100.0 \\
Missing data & 14 & 2.7 & \\
Total & 513 & 100.0 & \\
\hline
\end{tabular}

Abbreviation: $P$, probation.

showed that the average age for using drugs for the first time was $20.96 \pm 6.87$ years (range: $7-45$ years). It was discovered that $35.5 \%(n=182)$ of the total patients $(n=513)$ had previously been subjected to $\mathrm{P}$ or a similar judicial practice due to drug use, and $18.7 \%(\mathrm{n}=96)$ of them had undergone prior treatment due to drug addiction. The data regarding patients' education level are given in Table 2 and Figure 1.

Considering the distribution of the drugs cited by the patients, the most frequently used drug was cannabis. Drug use distribution is shown in Table 3.

In the evaluation conducted on the means of drug use, it was found that marijuana users and synthetic cannabinoid users smoke it, ecstasy and amphetamine users take them as pills, and heroin users $(\mathrm{n}=10)$ either snort $(\mathrm{n}=7,70 \%)$ or take it through injection $(n=3,30 \%)$.

Prior to starting the treatment, the patients were asked about their drug use frequency. Drug positivity was detected in the urine of these patients after the administration of a substance screening test within the last month. The drug use frequency figures, as declared by the patients, are given in Table 4.

In response to whether or not they smoked, or drank alcohol, $46 \%$ of the patients said they drank alcohol, and $70.2 \%$ of them said they smoked.

\section{Treatment results}

Three hundred and thirty-eight of the 513 (65.9\%) patients responded to the treatment. Age of the first drug use was younger, and duration of regular drug use was longer in nonresponders than responders $(P<0.05)$.

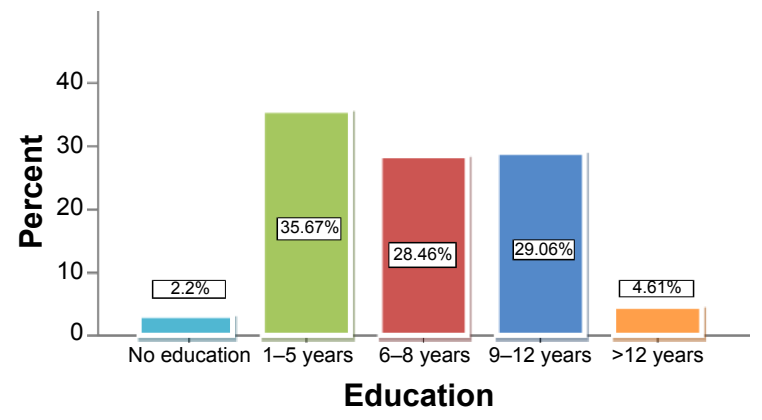

Figure I Distribution of patients according to their education levels.
Table 3 Distribution of the drugs used (5 years)

\begin{tabular}{llll}
\hline Drug & $\mathbf{n}$ & $\%$ & Valid \% \\
\hline Cannabis (marijuana) & 466 & 90.8 & 93.0 \\
Ecstasy & 7 & 1.4 & 1.4 \\
Heroin & 10 & 1.9 & 2.0 \\
Synthetic cannabinoid & 8 & 1.6 & 1.6 \\
Amphetamine & 1 & 0.2 & 0.2 \\
Other/multiple & 9 & 1.8 & 1.8 \\
Total & 501 & 97.7 & 100.0 \\
Does not admit to drug use & 12 & 2.3 & \\
Total & 513 & 100.0 & \\
\hline
\end{tabular}

All of the female patients positively responded to the treatment program, while $65.2 \%$ of males were responders. Also, $50 \%$ of patients who had undergone a prior treatment responded to the treatment program, but $69.5 \%$ of the ones who did not have a prior treatment anamnesis responded to the treatment program $(P<0.05)$.

In other parameters, there were no significant differences between responders and nonresponders.

\section{Discussion}

This study gives data on 513 patients who presented to the psychiatry polyclinic of STRH within the scope of P between October 2009 and December 2014. All of the study participants were diagnosed with a "drug addiction" following the conduct of a clinical interview and were thereby included in a 6-week treatment program.

The evaluation conducted on the distribution of drug addicts according to year found that the figure by year increased up to the year 2013 but slightly decreased in 2014 . The number of new patients in 2013 was significantly higher than the number found in other years. These results were obtained after verification through laboratory tests. The decrease seen in the addiction rate in 2014 was a promising outcome, but this result could be attributed to the fact that the use of substances such as synthetic cannabinoid, which cannot be detected in our urine analyses, could have been widespread during the period of the study (synthetic cannabinoids could be detected during only last two months of the study), making it possible that it passed by unnoticed. ${ }^{10}$

Table 4 Drug use frequency as declared by patients

\begin{tabular}{lll}
\hline & Number & $\%$ \\
\hline Everyday & 82 & 16.0 \\
2-6 days a week & 46 & 9.0 \\
I day a week or less & 118 & 23.0 \\
Did not use last month & 254 & 49.5 \\
At least one use in total & 500 & 97.5 \\
Never used & 12 & 2.3 \\
No answer & 1 & 0.2 \\
Total & 513 & 100.0 \\
\hline
\end{tabular}


In this study, responses from the patients showed that the age range for first use of a drug extended from the lowest age of 7 years up to the highest age of 45 years. The highest risk period found in the study was the mid-20s. A study conducted in 72 provinces of Turkey in 2002 revealed that drug use frequency was higher in the age group of 15-24 years than in the age group over 25 years. ${ }^{11}$ In another study conducted through $\mathrm{P}$ cases in Turkey, it was found that the youngest and oldest persons diagnosed with addiction were 17 years and 64 years, respectively, and that the average age was $32.47 \pm 10.55$ years. The ages of first drug use, however, were not specified in said study. ${ }^{12}$ Another study conducted on this issue showed that the average age of first drug use was 25.64 years range: $14-43$ years and that the average age of application was 33.79 years (range: $18-83$ years). ${ }^{13}$ These data are consistent with our data. Reports from the US demonstrated that drug use age decreased below 11 years, and that almost three-quarters of the users begin to use drugs below the age of 17 years. ${ }^{14}$ It has been well established throughout Europe and the world that drug use is a problem that primarily afflicts the young population., ${ }^{2,15}$

Considering the education levels of the patients, primary school graduates constitute the highest share. However, the distribution of secondary school- and high school graduates is similar, and college graduates also constitute a proportion of the patients. Comparable findings were detected in the studies conducted through $\mathrm{P}$ cases in Turkey. ${ }^{12,13,16}$ The relationship between drug addiction and education level has been shown by international studies as well. ${ }^{17,18}$ Raising awareness about drug addiction among all education levels of society seems to be a measure that needs to be taken. ${ }^{19,20}$

Most of the patients, in our study, lived with their families and had regular jobs. Although it is well known that drug addiction causes the user to become alienated from his/her family and stop going to work, our study is important for showing that our drug addicts do not always fit the conventional image of being "unemployed and alone", but on the contrary, any person in society is under the risk of drug addiction. Similar results were obtained by other studies made through $\mathrm{P}$ cases in Turkey. ${ }^{12,13,21}$ A review published in 2011 showed an inverse relationship between unemployment and drug use, where unemployment led to drug use and likewise, drug use led to unemployment. ${ }^{22}$

According to our data on distribution of particular drugs, marijuana is the most frequently used substance. Heroin was the second with $1.9 \%$, and in our 2-month data analysis, synthetic cannabinoid has reached $1.6 \%$. Considering that other data reflect the result of almost 5 years and both use and detection of synthetic cannabinoid have only recently started, 2015 data on this issue are estimated to be more realistic. Similar results were received for the studies conducted through $\mathrm{P}$ cases in Turkey. ${ }^{12,13}$ In 2014, cannabis remained the most widely consumed drug worldwide. Global annual cannabis use prevalence is estimated to be between $2.7 \%$ and $4.9 \%$ of the population aged 15-64 years. ${ }^{2}$ Moreover, a majority of the studies conducted on drug addiction report that marijuana is the most widely used illegal substance, both in Turkey and the rest of the world. ${ }^{23-26}$ In the study's patient provided responses to drug use frequency, final results showed that $16 \%$ of the patients used drugs daily, 9\% used them 2-6 days a week, and 23\% used them at most once a week. One of the more interesting outcomes of this study was seen in the patients who had tested positive for drug use. Of the patients who were determined, via a urine analysis performed within 35 days pursuant to $\mathrm{P}$ practices, to have substance positivity, $45.5 \%$ of them declared that they had not used drugs within the last month and $2.3 \%$ of them stated that they had never used drugs. This particular matter requires that further studies be performed, wherein information about the patients can be verified through toxicological analyses.

In this study, early onset of drug use, longer durations of drug use, male sex, and having a prior treatment history (except judicial process) were related with negative response to the treatment program in immediate evaluations at the end of the program. These results are in line with previous studies except $\operatorname{sex}^{12,27,28}$. Having a prior treatment anamnesis is supposed as being a chronic user with at least one recurrent treatment and drug use periods. Interestingly, prior judicial practices were not related with treatment response. We thought that judicial procedure may have a preventative role on substance use disorders but not effective enough to meet the expectations in chronic and long-term users. Long-term results are needed to make a clear evaluation, but according to results of this study, alternative models of treatment programs should be researched for long-term users and treatment-resistant patients.

This study is beneficial for its use of a strong sample in providing 5-year data on the individuals diagnosed with drug addiction within the scope of judicial P in Sakarya. Furthermore, the information obtained, the first of its kinds in the province of Sakarya, offers a general profile of the social status of the drug addicts. The retrospective design of the study acted as a constraint, however, as only a small amount of data approved by the ethics committee for use in file records was obtained. More detailed prospective studies will facilitate a better understanding of the addiction profile.

\section{Conclusion}

According to this study, it was determined that the substance most frequently used by the patients undergoing addiction treatment within the scope of $\mathrm{P}$ in the province of Sakarya is 
marijuana. The risk of drug addiction can affect any individual in society, regardless of their education, occupation, or social support levels. Treatment response is related with age of first use of drugs, duration of use drugs, and prior treatment anamnesis of the patients. Long-term studies are needed to determine alternative models of treatment especially in chronic patients.

\section{Disclosure}

The authors report no conflicts of interest in this work.

\section{References}

1. Republic of Turkey Ministry of Interior Turkish National Police Anti-Smuggling and Organized Crime Department, National Report (2012 Data) to the EMCDDA 2013 by the Reitox National Focal Point: Turkey New Developments, Trends, Selected Issues; 2013. Available from: http://www.emcdda. europa.eu/html.cfm/index228535EN.html. Accessed May 16, 2014.

2. UNODC. United Nations Office on Drugs and Crime, World Drug Report 2014 (United Nations Publication, Sales No. E.14.XI.7); 2014. Available from: https://www.unodc.org/documents/wdr2014/ World_Drug_Report_2014_web.pdf. Accessed 2015.

3. Peters RH, Wexler HK. Substance Abuse Treatment for Adults in the Criminal Justice System: Treatment Improvement Protocol TIP 44. Rockville, MD: Center for Substance Abuse Treatment; 2005.

4. Nolan JL Jr. Drug treatment courts and the disease paradigm. Subst Use Misuse. 2002;37(12-13):1723-1750.

5. Ögel K, Karadağ F, Can Y, Altintoprak E, Coskunol H. Denetimli Serbestlik Bağımlılık Programı [Probation Addiction Programs]. 1 ed. Ankara: Turkish Psychiatry Association; 2010. Turkish.

6. Bicak V, Grieves E. Turkish Penal Code. Ankara: Seckin Inc.; 2009.

7. Yenisey F. Turkish Penal Procedure Code. Istanbul: Beta Inc.; 2009.

8. The Law on Amendment of Turkish Criminal Code and Some Other Laws 6545, published in the Official Gazette (June 28, 2014). Available from: http://www.resmigazete.gov.tr/eskiler/2014/06/20140628-9.htm. Accessed December 21, 2014.

9. TBMM [The Grand National Assembly of Turkey]. Denetimli serbestlik ve yardim merkezleri ile koruma kurullari yönetmeliği [A probatın and assistance centers and protection committee regulation]; 2007. Available from: http://www.ttb.org.tr. Accessed December 21, 2014.

10. Favretto D, Pascali JP, Tagliaro F. New challenges and innovation in forensic toxicology: focus on the "new psychoactive substances". J Chromatogr A. 2013;1287:84-95.

11. Isıklı S, Iraklı M. Türkiye'de madde kullanımı ve bağımlılığı profili araştırması: 2002 yılı madde kullanımı geniş alan araştırması [Investigation of substance use and addiction profile in Turkey: Year of 2002, broad region research of substance use]. Turkish Psychological Association. 2002;4:55-65. Turkish.

12. Karadeniz H, Birincioğlu I, Seçilmişoglu B, Savaş H, Zazoğlu S. Trabzon'da denetimli serbestlik ve yardim merkezi şube müdürlüğü'nde madde bağimliliği nedeniyle kayitli olgularda toksikolojik analiz bulgulari ve tedavi uygulamalarinin değerlendirilmesi [Evaluation of toxicological analysis results and treatment applications in cases registered for drug addiction at parole branch office of Trabzon]. The Bulletin of Legal Medicine. 2009:14(2):80-87. Turkish.

Neuropsychiatric Disease and Treatment

\section{Publish your work in this journal}

Neuropsychiatric Disease and Treatment is an international, peerreviewed journal of clinical therapeutics and pharmacology focusing on concise rapid reporting of clinical or pre-clinical studies on a range of neuropsychiatric and neurological disorders. This journal is indexed on PubMed Central, the 'PsycINFO' database and CAS,
13. Bahçeci B, Helvacı Çelik F, Kandemir G, Güveli H, Polat S. Evaluation of the patients applied by probation referring to a training and research hospital in the Eastern Black Sea region: a one-year retrospective study. Turk J Forensic Med. 2014;28(1):1-9. Turkish.

14. SAMHSA. The TEDS Report: Age of Substance Use Initiation among Treatment Admissions Aged 18 to 30. Rockville, MD: Substance Abuse and Mental Health Services Administration (SAMHSA), Center for Behavioral Health Statistics and Quality; 2014.

15. EMCDDA. European Drug Report: Trends and Developments, European Monitoring Centre for Drugs and Drug Addiction (EMCDDA). Luxembourg: Office for Official Publications of the European Communities; 2013.

16. Zorlu N, Turk H, Manavgat AI, Karadas B, Gulseren S. Retrospective studying of sociodemographic, clinical characteristics and extent of alcohol use disorder among patients applied by probation. Anatol $J$ Psychiatry. 2011;12(4):253-257.

17. Kraus L, Augustin R, Frischer M, Kümmler P, Uhl A, Wiessing L. Estimating prevalence of problem drug use at national level in countries of the European Union and Norway. Addiction. 2003;98(4):471-485.

18. van Ours JC, Williams J. Why parents worry: initiation into cannabis use by youth and their educational attainment. $J$ Health Econ. 2009; 28(1):132-142.

19. Bangert-Drowns RL. The effects of school-based substance abuse education - meta-analysis. J Drug Educ. 1988;18(3):243-264.

20. Porath-Waller AJ, Beasley E, Beirness DJ. A meta-analytic review of school-based prevention for cannabis use. Health Educ Behav. 2010;37(5):709-723.

21. Substance Abuse and Mental Health Services Administration. Results from the 2013 National Survey on Drug Use and Health: Summary of National Findings. H-48, HHS Publication No. (SMA) 14-4863. Rockville, MD: Substance Abuse and Mental Health Services Administration; 2014.

22. Henkel D. Unemployment and substance use: a review of the literature (1990-2010). Curr Drug Abuse Rev. 2011;4(1):4-27.

23. Bulut M, Savaş HA, Cansel N, Selek S, Kap Ö, Yumru M. Gaziantep Üniversitesi Alkol ve Madde Kullanim Bozukluklari birimine başvuran hastalarin sosyodemografik özellikleri [Sociodemographic characteristics of patients, applied to Substance Usage Disorders Unit of Gaziantep University]. J Depend. 2006;7:65-70. Turkish.

24. Evren EC, Çakmak D. Alkol ve madde kullananların özellikleri: 2000 yılına ait AMATEM'e yatan hasta verilerinin incelenmesi [Characteristics of substance and alcohol users:Investigation of inpatient data at the AMATEM in the year of 2000]. Dusunen Adam: The Journal of Psychiatry and Neurological Sciences. 2001;14:142-149.Turkish.

25. Weich L, Pienaar W. Occurrence of comorbid substance use disorders among acute psychiatric inpatients at Stikland Hospital in the Western Cape, South Africa. Afr J Psychiatry. 2009;12(3):213-217.

26. Bonsack C, Camus D, Kaufmann N, et al. Prevalence of substance use in a Swiss psychiatric hospital: interview reports and urine screening. Addict Behav. 2006;31(7):1252-1258.

27. Chen C-Y, Storr CL, Anthony JC. Early-onset drug use and risk for drug dependence problems. Addict Behav. 2009;34(3):319-322.

28. Becker JB, Hu M. Sex differences in drug abuse. Front Neuroendocrinol. 2008;29(1):36-47.

and is the official journal of The International Neuropsychiatric Association (INA). The manuscript management system is completely online and includes a very quick and fair peer-review system, which is all easy to use. Visit http://www.dovepress.com/testimonials.php to read real quotes from published authors. 